\title{
Enzyme production by soil filamentous fungi under solid-state fermentation in banana stalk
}

\author{
Fernanda Castro Pires dos Santos', Joice Raísa Barbosa Cunha', \\ Fábia Giovana do val de Assis², Patrícia Lopes Leal ${ }^{*}$
}

\author{
'Federal University of Bahia, Vitória da Conquista, Brazil \\ ${ }^{2}$ Federal University of Viçosa, Viçosa, Brazil \\ *Corresponding author, e-mail: lealpat@yahoo.com.br
}

\begin{abstract}
The adequate disposal of agricultural waste is one of the major concerns of public officials and a research challenge to obtain sustainable solutions to the problem. In this sense, the objective of this study was to evaluate the banana leaf stalk use as substrate in solid-state fermentation (SSF) for production of amylolytic and cellulolytic enzymes by Penicillium spp. LEMI All strain grown under different substrate concentrations, $\mathrm{pH}$ and temperature. Effects of different $\mathrm{pH}$ conditions (5.0 and 6.0), temperature $\left(30\right.$ and $35^{\circ} \mathrm{C}$ ) and substrate concentration 70 and $90 \%$ (in relation to the final volume) of the fermentation were evaluated over 120 hours of fermentation. The results indicated that Penicillium spp. LEMI A 11 was able to use the banana stalk as substrate under SSF. The maximum activities for amylase dextraining, amylase saccharifying and CMCase were $0.18 ; 0.13$ and $04 \mathrm{U.g}^{-1}$, respectively. The effect of environmental factors related to the substrate concentration was significant for saccharifying amylase and CMCase activity only. The interaction between the environmental factors tested was significant for the dextrinizing amylase activity only. It was verified enzyme activity reduction after 96 hours of fermentation for all enzymes. It concluded that banana stalk is an alternative carbon source to be used in SSF for enzyme production by of Penicillium spp. LEMI A1 1.
\end{abstract}

Keywords: agroindustrial wastes, enzyme activity, Penicillium spp

\section{Introduction}

Brazil is the fourth largest banana producer country in the world $(7,098,350 \mathrm{t} /$ year), with at least 200 tons/year of residues composed by pseudostem, leaves and stalks (Bastianello et al., 2009; Souza et al al., 2010). The banana stalks and pseudostems form the bulk of the waste, which implies high transport costs and, consequently, its accumulation in the environment, with potential environmental and phytosanitary problems (Soffner, 2001).

The lignocellulosic composition of banana leaf suggests that this residue is a promising raw material for the production of cellulosic pulp, making it possible to add value to the residue and reduce environmental impacts (Oliveira et al., 2007). According to Pandey et al. (2008), the enzymes production from biological conversion techniques using agroindustrial residues has been increasingly studied due to its applicability in different industrial sectors, especially the food and beverage, textile, paper and pharmaceutical industries.

The solid-state fermentation (SSF), which is characterized by the growth of microorganisms in solid substrates, in the absence or low free water content, has been indicated for the production of enzymes from agroindustrial 
residues as a substrate (Rahardjo et al., 2006). This is due to some advantages presented by SSF, as follows (Singhania et al., 2010): the enzymes are produced by microorganisms directly on substrates insoluble in water that makes easier their recovery; the enzymes produced in SSF are less susceptible to substrate inhibition problems and present higher stability to temperature and $\mathrm{pH}$ variations.

Filamentous fungi (Trichoderma, Penicillium, Aspergillus and Humicola) are potential enzyme producers in SSF process, since the solid surface culture is the fungi natural environment, which makes it easier to preserve and control the microorganisms morphological cycle (Hu et al., 2011).

Despite the advantages presented by the solid-state fermentation process on enzyme production, it should be emphasized that environmental conditions such as temperature, $\mathrm{pH}$, water activity, oxygen level, nutrient concentration and products used can significantly affect cell growth and product formation (Pandey et al., 2008; Rodríguez-Zúñiga et al., 2011). Due to such factors, it is essential that the environmental parameters are adequate according to the physiological demands of the enzyme-producing biological agent and the substrate physical-chemical characteristics. Therefore, the present study had as objective to evaluate the banana leaf stalk use as substrate in solid-state fermentation (SSF) for production of amylolytic and cellulolytic enzymes by Penicillium spp. LEMI A11 strain grown under different substrate concentrations, $\mathrm{pH}$ and temperature.

\section{Material and Methods}

The banana stalks were supplied by CEASA - Center of Commercialization of Vitória Conquista, Bahia, Brazil. The samples were sent to the Laboratory of Enzymology and Industrial Microbiology of the Federal University of Bahia IMS/CAT, where the material was mechanically processed without a specific determination of particle size. Subsequently, the crushed material was dried outdoors, distributed in plastic bags and stored at room temperature.

The fungal strain used was Penicillium spp. LEMI Al1 belonging to the collection of microbial cultures of the Laboratory of Enzymology and Industrial Microbiology, Federal University of Bahia, Anísio Teixeira campus, in Vitória da Conquista, Bahia, Brazil. The fungal strain reactivation was performed by cultivating the microorganism in petri dishes containing potato-dextrose-agar medium (PDA HIMEDIA pH 5.02), for 48 hours.

The experiment was set up in a completely randomized design, arranged in a factorial arrangement (three factors in two levels): $\mathrm{pH}$ (5.0 and 6.0), temperature (30 and $35^{\circ} \mathrm{C}$ ) and substrate concentration (70 and $90 \%$ in relation to the final volume), in order to verify the maximum enzymatic activity of the fungal isolate cultivated under solid-state fermentation in banana stalks (Table 1).

The fermentation was performed in 125 $\mathrm{mL}$ Erlenmeyer flasks containing $50 \mathrm{~mL}$ of minimal medium (1 g.L $\mathrm{L}^{-1}$ of ammonium sulfate $\left[\left(\mathrm{NH}_{4}\right)_{2} \mathrm{SO}_{4}\right]^{\prime}$ $2 \mathrm{~g} . \mathrm{L}^{-1}$ of potassium phosphate $\left(\mathrm{KH}_{2} \mathrm{PO}_{4}\right), 2.8 \mathrm{~g} \cdot \mathrm{L}^{-1}$ of sodium phosphate $\left(\mathrm{Na}_{2} \mathrm{HPO}_{4}\right), 0.05 \mathrm{~g} . \mathrm{L}^{-1}$ of

Table 1. Complete factorial experimental planning used for statistical analyses of $\mathrm{pH}$, temperature and substrate concentration effects on activity of amylolytic and cellulolytic enzymes.

\begin{tabular}{cccc}
\hline Treatments & $\mathrm{pH}$ & $\begin{array}{c}\text { Temperature } \\
\left({ }^{\circ} \mathrm{C}\right)\end{array}$ & $\begin{array}{c}\text { Substrate } \\
\text { concentration }(\%) \\
(\mathrm{w} / \mathrm{v})\end{array}$ \\
\hline T1 & 5 & 30 & 70 \\
T2 & 5 & 30 & 90 \\
T3 & 5 & 35 & 70 \\
T4 & 5 & 35 & 90 \\
T5 & 6 & 30 & 70 \\
T6 & 6 & 30 & 90 \\
T7 & 6 & 35 & 70 \\
T8 & 6 & 35 & 90 \\
\hline
\end{tabular}


iron (III) ammonium citrate $\left(\mathrm{C}_{6} \mathrm{H}_{8} \mathrm{O}_{7} \cdot \mathrm{Fe}^{+3} \cdot \mathrm{H}_{3} \mathrm{~N}\right)$, $0.002{\mathrm{~g} . \mathrm{L}^{-1}}^{-1}$ of magnesium sulfate heptahydrate $\left(\mathrm{MgSO}_{4} \cdot 7 \mathrm{H}_{2} \mathrm{O}\right), 0.01$ g.L-1 of yeast extract) and autoclaved banana stalk residues, in order to obtain the final volume concentrations of 70 and $90 \%(\mathrm{w} / \mathrm{v})$. The enriched substrate $\mathrm{pH}$ was adjusted to 5 and 6 using $\mathrm{HCl}$. The fungal isolate inoculation was performed by adding small disks of culture medium containing fungal mycelium, following the methodology described by Sena et al. (2006). After inoculation, the duplicate Erlenmeyers were incubated in chambers at 30 and $35^{\circ} \mathrm{C}$ during 4 days.

Aliquots of $1 \mathrm{~mL}$ of each treatment were collected (crude enzymatic extract) every 24 hours, mixed with $40 \mathrm{~mL}$ of distilled water, homogenized, centrifuged at 10,000 rpm for 5 minutes and vacuum filtered using qualitative filter paper with a weight of $80 \mathrm{~g} / \mathrm{m}^{2}$. The supernatants obtained were used as enzyme crude extract to determine the enzymatic activities (Nizamuddin et al., 2008).

For the dextrinizing amylase and saccharifying activity quantification, $40 \mu \mathrm{L}$ of sodium acetate buffer ( 500 mmol..L-1, pH 6.0), 100 $\mu \mathrm{L}$ of $0.5 \%$ starch solution $(\mathrm{w} / \mathrm{v})$, and $60 \mu \mathrm{L}$ of the aliquot removed from the fermentation medium. The tubes containing this mixture were incubated at $40{ }^{\circ} \mathrm{C}$ for 30 minutes and withdrawn for addition of $200 \mu \mathrm{L}$ of previously prepared iodine/ iodide solution and $200 \mu \mathrm{L}$ of acetic acid solution to promote the reaction shutdown. Distilled water was added to the mixture to reach the final volume of $10 \mathrm{~mL}$ and then the determination was performed in a spectrophotometer at 540 nm absorbance.

For saccharifying amylase quantification, $40 \mu \mathrm{L}$ of sodium acetate buffer $\left(500 \mathrm{mmol} \mathrm{L}^{-1}\right.$, $\mathrm{pH}$ 6.0), $100 \mu \mathrm{L}$ of $0.5 \%$ starch solution (w/v) and $60 \mu \mathrm{L}$ of the aliquot from the fermentative medium were used. The tubes containing this mixture were incubated at $40{ }^{\circ} \mathrm{C}$ for 30 minutes and withdrawn for addition of $800 \mu \mathrm{L}$ of a preprepared dinitrosalicylic acid solution (DNS). The mixture was boiled for 5 minutes and then $9.0 \mathrm{~mL}$ of distilled water was added followed by homogenization. The enzymatic activity was obtained in spectrophotometer at $660 \mathrm{~nm}$ absorbance (Miller, 1959).

The proteolytic activity of CMCase was determined according to Siqueira et al. (2010), using $100 \mu \mathrm{L}$ of carboxymethylcellulose (1\%) and $50 \mu \mathrm{L}$ of an aliquot from the fermentative medium. The tubes containing this mixture were incubated at $50{ }^{\circ} \mathrm{C}$ for 30 minutes and withdrawn for addition of $300 \mu \mathrm{L}$ of pre-prepared dinitrosalicylic acid solution (DNS). Then the mixture was boiled for 10 minutes and $1.5 \mathrm{~mL}$ of distilled water was added. The control received the same treatment, replacing the crude enzymatic extract by distilled water. The absorbance reading was performed in a spectrophotometer at $540 \mathrm{~nm}$.

For the enzyme activity studies, a control reaction for each enzyme was prepared with same treatment, but replacing the crude enzymatic extract by distilled water. The enzyme activity unit (U. $\left.\mathrm{g}^{-1}\right)$ was defined according to the amount of enzyme capable of releasing $1 \mu \mathrm{mol}$ of product (reducing sugars) per gram of sample (polysaccharides) under the reaction conditions, using as standard the glucose monomers curve (amylase, CMCase).

The average activity of each enzyme, at the end of 24 hours, over four days was submitted to analysis of variance (ANOVA). The effect of the individual factors and the interaction between them was evaluated from the activity averages of each enzyme obtained at the end of the fermentation process. The effect of the fermentation time on each enzyme activity was evaluated independently of the treatments. Significant differences $(p<0.05)$ between the means were determined by the Scott Knott test, using Assistat (Silva \& Azevedo, 2009) statistical software and graphics were elaborated with Action Estatcamp Software (Statistical Team, 2014).

\section{Results and Discussion}

The fungal isolate Penicillium spp. LEMI A11 presented metabolic ability for production of dextrinizing amylase, saccharifying and CMCase, 
independently of the treatments and times applied to the solid state fermentation, using banana stalk as substrate (Table 2). According to Siqueira et al. (2010) this residue contains considerable proportions of total carbohydrates (36.7\%), beyond celluloses (52.9\%), hemicelluloses (17.4\%) and lignin (9.4\%) among the chemical constituents and suggesting that banana stalk could be an alternative and promising carbon source to be used as substrate for fermentative processes. Medeiros et al. (2008) also verified significant results of banana stalk as substrate for hemicelluloses production by filamentous fungi.

Table 2. Activity $\left(\mathrm{U}^{\left.-\mathrm{g}^{-1}\right)}\right.$ of dextrinizing amylase, saccharifying amylase and CMCase enzymes produced by Penicillium sp. LEMI A 11 cultivated under solid-state fermentation containing banana stalks as carbon source.

\begin{tabular}{cccccccccccccc}
\hline & \multicolumn{3}{c}{$\begin{array}{c}\text { Dextrinizing amylase } \\
\text { activity }\end{array}$} & \multicolumn{4}{c}{$\begin{array}{c}\text { Saccharifying amylase } \\
\text { activity }\end{array}$} & \multicolumn{4}{c}{ CMCase activity } \\
Treatments
\end{tabular}

Significant effects of the treatments studied were observed for the activities of saccharifying amylase and CMCase enzymes at the end of each solid state culture time interval (Table 2). For dextrinizing amylase enzyme, no significant effect of the treatments was observed, indicating that the production of this enzyme by Penicilium spp. LEMI A11 strain under fermentation in banana stalks remained unchanged, independently of $\mathrm{pH}$, temperature and substrate concentration values proposed in this study. On the other hand, it is observed that $\mathrm{Tl}$ promoted the higher average values for saccharifying amylase activity ( $p<0.05)$ at all time intervals $\left(0.13,0.14,0.13\right.$ and $0.12{\mathrm{U} . g^{-1}}^{-1}$ at 24, 48, 72 and 96 hours, respectively). For CMCase activity, treatments promoted different effects ( $p<0.05$ ) within each fermentation time interval (Table 2). T7 provided a higher CMCase activity mean at 24-hour fermentation interval $\left(0.34\right.$ U.g $\left.\mathrm{g}^{-1}\right)$, whereas at 48 hours of fermentation, T3, T5 and T7 promoted higher enzyme activity ranging from 0.38 to $0.40 \mathrm{U} \cdot \mathrm{g}^{-1}$. At 72 and 96 hours intervals, the treatments that allowed higher averages of CMCase activity ( $p<0.05$ ) were, respectively, T3 $\left(0.30 \mathrm{U} . \mathrm{g}^{-1}\right)$ and T4 $\left(0.36 \mathrm{U} . \mathrm{g}^{-1}\right)$.
The maximum activity values for amylase (dextrinizing and saccharifying) recorded in this study are considered low in comparison to those of Gusmão et al. (2014) that recorded

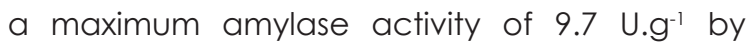
Aspergillus spp. cultivated under SSF in coffee husk after 72 hours. This can be explained by the high lignocellulosic content present in banana stalk, indicating the need of easier assimilation material to the fermentation process to promote the amplified expression of amylolytic activities.

For other agroindustrial residues used as fermentation substrate for enzyme production, the need for nutritional supplementation in culture medium has already been reported: Kunamneni et al. (2005) reported maximum amylolytic activity of 534 U.g-1 amylase from the Thermomyces lanuginosus fungus culture, under SSF in wheat meal supplemented with starch and peptone. Anto et al. (2006) observed maximum production of amylase (271.2 U.g $\mathrm{g}^{-1}$ ) by Aspergillus sp. fungus using wheat bran as substrate added organic nitrogen (yeast extract and peptone extract).

Among the enzymes evaluated in the present study, the most promising results 
were verified for CMCase, whose values were compatible to those verified by Rodriguez-Zúñiga et al. (2011) who reported CMCase activity of 0.3

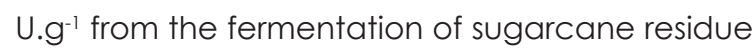
by Aspergillus niger. The other way, Camassola \& Dillon (2007) obtained 1 U.g ${ }^{-1}$ CMCase activity by Penicillium echinulatum under SSF in sugarcane bagasse, after five days of cultivation and Saha \& Cotta (2014) obtained maximum amylase values of 7.25 ; 14.25; and $13.5 \mathrm{U.mg}^{-1}$ at 24, 48, and 72 hours, respectively, using wheat bran as substrate.

The effect of the independent factors ( $\mathrm{pH}$, temperature and substrate concentration) was significant ( $p<0.05$ ) only for saccharifying amylase activity and CMCase related to substrate concentration (Table 3). Silva et al. (2009) also observed a significant effect of substrate concentration on total cellulases production by Aspergillus phoenicis, using grape residue as substrate. In the present study, it is attributed the substrate concentration effect on saccharifying amylase and CMCase activities to the moisture percentage in the total mass of the substrate, which was higher in the $70 \%$ substrate treatment. According to Gervais \& Molin (2003), moisture is the environmental factor that most affects the SSF process, and reduced moisture levels lead to lower growth in relation to the optimal and low substrate degree actually used. The interaction between the factors was significant only for the dextrinizing amylase activity (Table 3). The effect of the interaction between the factors on dextrinizing amylase activity suggested that, for its production, the synergy between $\mathrm{pH}$, temperature and substrate concentration levels was important, even though each factor had no effect, independently, on the process.

Table 3. Probability of the effects $(\mathrm{P})$ of $\mathrm{pH}$, temperature and substrate concentration and the interactions among them in relation to the average values for dextrinizing amylase, saccharifying amylase and CMCase enzymes produced within the fermentation process under solid-state fermentation containing banana stalks as carbon source.

\begin{tabular}{|c|c|c|c|c|c|c|c|c|c|c|}
\hline \multirow{2}{*}{$\begin{array}{c}\text { Enzymatic } \\
\text { activity }\end{array}$} & \multicolumn{2}{|c|}{$\mathrm{pH}$} & \multicolumn{2}{|c|}{$\begin{array}{c}\text { Temperature } \\
\left({ }^{\circ} \mathrm{C}\right)\end{array}$} & \multicolumn{2}{|c|}{$\begin{array}{c}\text { Substrate } \\
(\%)\end{array}$} & \multirow[t]{2}{*}{11} & \multirow[t]{2}{*}{12} & \multirow[t]{2}{*}{13} & \multirow[t]{2}{*}{14} \\
\hline & 5 & 6 & 30 & 35 & 70 & 90 & & & & \\
\hline $\begin{array}{c}\text { Dextrinizing } \\
\text { amylase }\end{array}$ & $0.15 \mathrm{a}$ & $0.16 \mathrm{a}$ & $0.16 \mathrm{a}$ & $0.16 \mathrm{a}$ & $0.16 \mathrm{a}$ & $0.16 \mathrm{a}$ & NS & NS & NS & $P<0.05$ \\
\hline $\begin{array}{c}\text { Saccharifying } \\
\text { amylase }\end{array}$ & $0.08 \mathrm{a}$ & $0.05 \mathrm{a}$ & $0.08 \mathrm{a}$ & $0.06 \mathrm{a}$ & $0.05 \mathrm{~b}$ & $0.08 \mathrm{a}$ & NS & NS & NS & NS \\
\hline CmCase & $0.31 \mathrm{a}$ & $0.32 \mathrm{a}$ & $0.32 \mathrm{a}$ & $0.32 \mathrm{a}$ & $0.29 \mathrm{~b}$ & $0.35 \mathrm{a}$ & NS & NS & NS & NS \\
\hline
\end{tabular}

concentration; 14: Interaction between $\mathrm{pH}$, temperature and substrate concentration. Average values of each factor followed by the same letter are not different by Scott Knott test $(\mathrm{P}>0.05)$.

The fermentation time was evaluated as a treatment-independent variable, as shown in Figure 1. For all the enzymes the reduction of the enzymatic activity was verified after 96 hours of fermentation. However, only for the dextrinizing amylase activity, there was a significant difference $(\mathrm{p}<0.05)$ between the time intervals (Figure 1A). The reduction on enzymatic activity to amylase after 96 hours of SSF can be attributed to a possible nutrient depletion or accumulation of products that inhibit enzymatic synthesis or microbial growth (Shafique et al., 2009). For the other enzymes evaluated in this study, no significant effect $(p<0.05)$ of the time was recorded, although maximum activities were observed after 48 and 72 hours of fermentation (Figure 1B and C). The increase of the enzymatic activity after 48 hours should be related to the sugar consumption, generated until then, causing substrate depletion and reactivating the enzyme expression mechanism as verified by Whitaker (1994).

\section{Conclusions}

The banana stalk is as an interesting alternative substrate for fermentation process, to obtain the enzymes, especially CMCase, by the isolate Penicillium spp. LEMI A11. However, 

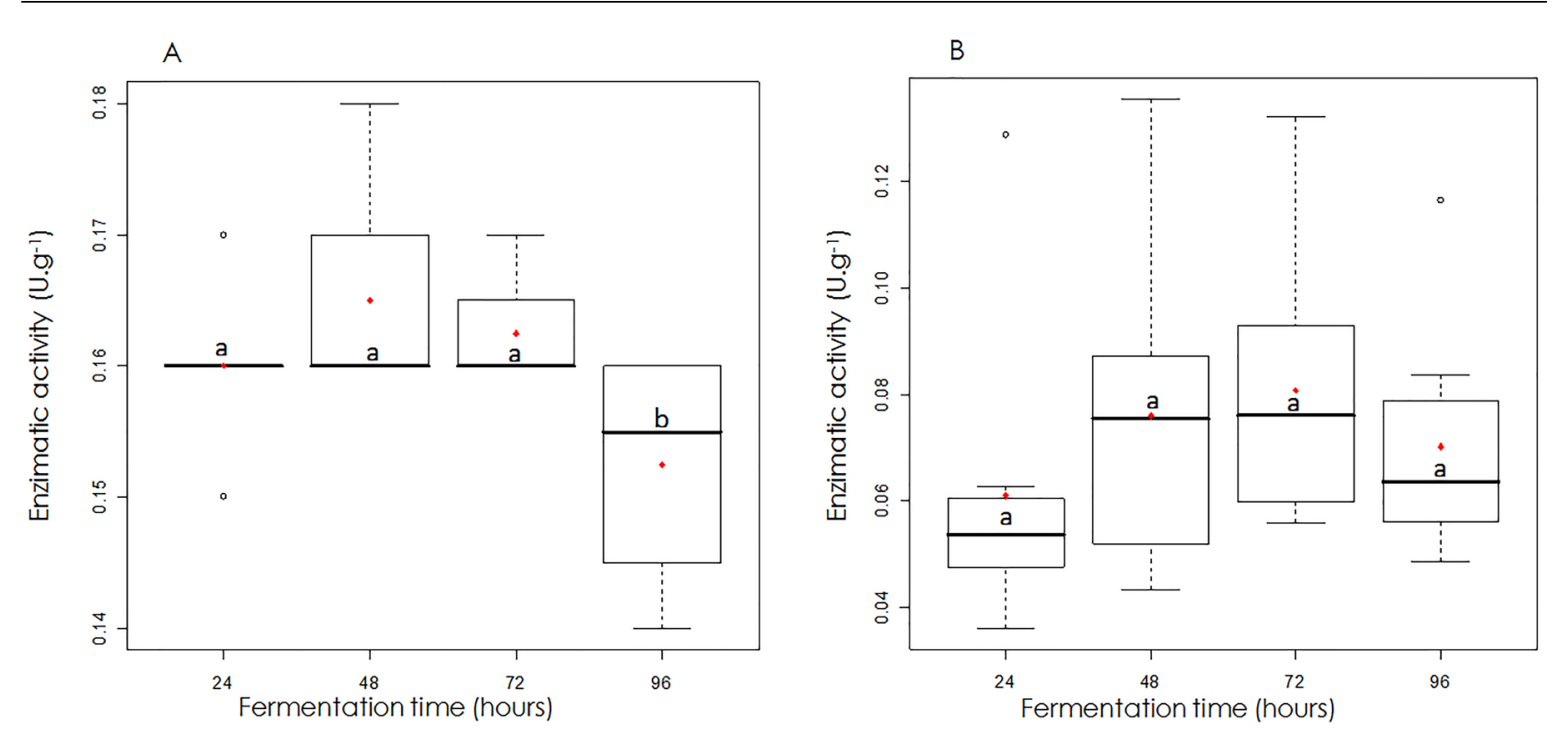

C

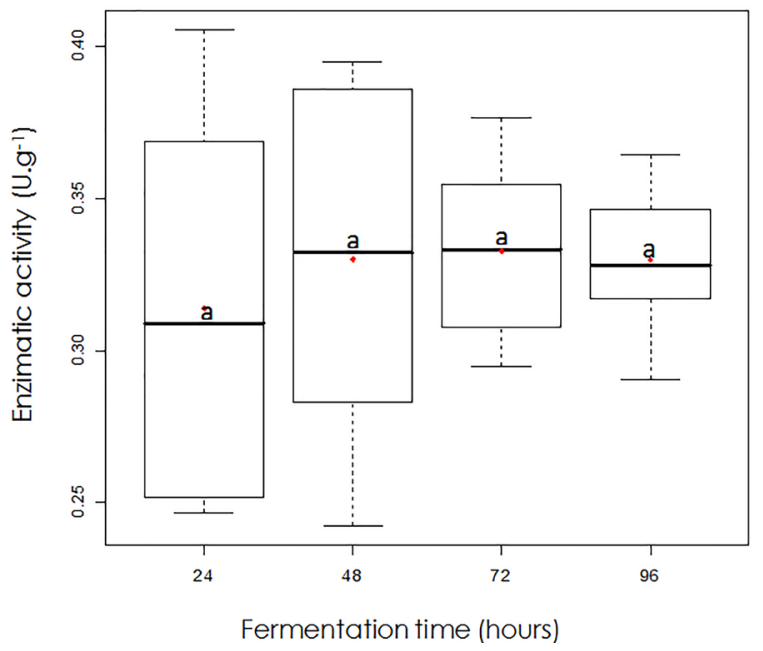

Figure 1. Activity $\left(U \cdot \mathrm{g}^{-1}\right)$ of dextrinizing amylase (A), saccharifying amylase (B) and CMCase (C) enzymes as a function of time under solid-state fermentation independently of $\mathrm{pH}$, temperature and substrate concentration. Bars with the same letter are not different by Scott Knott test $(P>0.05)$.

substrate nutritional supplementation is suggested in order to reach higher production yields of the enzymes by the fungal isolate. The environmental variables evaluated in this study ( $\mathrm{pH}$, temperature and substrate concentration) did not significantly interfere in dextrinizing amylase activity individually. The concentration of $90 \%$ of banana stalk in relation to the final volume of the fermented, provided higher saccharifying amylase and CMCase, activity whether compared to the $70 \%$ concentration. The fermentation time affected the dextrinizing amylase activity only, decreasing of the activity of this enzyme when the fermentation reached 96 hours.

\section{Acknowledgements}

Authors thank to the National Council for Scientific and Technological Development (CNPq), the State of Bahia Research Foundation (FAPESB) and the Federal University of Bahia, for granting the study and projects.

\section{References}

Anto, H., Trivedi, U.P., Patel, K.C. 2006. Glucoamylase productionby solid-state fermentation using rice flake manufacturing wasteproducts as substrate. Bioresource Technology 97: 1161-1166.

Bastianello, S.F., Testa, R.C., Pezzin, A.P.T., Silva, D.A.K. 2009. Avaliação das propriedades físicas e mecânicas de papéis reciclados artesanais com resíduos de bananeira ou palha de arroz. Revista Matéria 14: 1172 - 1178. 
Camassola, M., Dillon, A.J.P. 2009. Biological pretreatment of sugar cane bagasse for the production of cellulases and xylanases by Penicillium achinulatum. Industrial Crops and Products 29: 642-647.

Cavalcanti, M.A.Q., Oliveira, L.G., Fernandes, M.J., Lima, D.M. 2006. Fungos filamentosos is isolados do solo em municípios na região Xingó, Brasil. Acta Botanica Brasilica 20: 831-837.

Chávez, R., Bull, P., Eyzaguirre, J. 2006. The xylanolytic enzyme system from the genus Penicillium. Journal of Biotechnology 4: 413-433.

da Silva, L.M., Stamford, T.L.M. 2010. Produção do complexo celulolítico a partir do engaço da bananeira (Musa spp.). 138f. (PhD Thesis) Federal University of Pernambuco, Recife, Brazil.

Gervais, P., Molin, P. 2003. The role of water in solidstate fermentation. Biochemical Engineering Journal 13: 85-101.

Gusmão, R.O., Ferraz, L.M., Rêgo, A.P.B., Assis, F.G.V., Leal, P.L. 2014. Produção de enzimas por Aspergillus spp. sob fermentação em estado sólido em casca de café. Scientia Plena 10: 4-8.

Hu, H.L., Van Den Brink, J., Gruben, B.S., Wosten, H.A.B., GU, J.B., De Vries, R.P. 2011. Improved enzyme production by co-cultivation of Aspergillus niger and Aspergillus oryzae and with other fungi. International Biodeterioration and Biodegradation 65: 248-252.

Kunamneni, A., Permaul, K., Singh, S. 2005. Amylase Productionin Solid State Fermentation by the Thermophilic Fungus Thermomyces lanuginosus. Journal of Bioscience and Bioengineering 100:168-171.

Medeiros, R.G., Soffner, M.L.A.P., Thomé, J.A., Cacais, A.O.G., Estelles, R.S., Salles, B.C., Ferreira, H.M., Lucena Neto, S.A., Silva-Jr, F.G., Filho, E.X.F. 2008. The production of hemicellulases by aerobic fungi on medium contanining residues of banana plant as substrate. Biotechnology Progress 16: 522-524.

Miller, G.L. 1959. Use of dinitrosalicylic acid reagente for determination of reducing sugar. Analytical Chemistry 31: 426-428.

Nizamuddin, S., Sridevi, A., Narasimha, G. 2008. Production of beta-galactosidase by Aspergillus oryzae in solid-state fermentation. African Journal of Biotechnology 7: 1096-1100.

Oliveira, L., Cordeiro, N., Evtuguin, D.V., Torres, I.C., Silvestre, A.J.D. 2007. Chemical composition of different morphological parts from 'Dwarf Cavendish' banana plant and their potential as a non-wood renewable source of natural products. Industrial Crops and Products 26: 163-172.
Pandey, A., Soccol, C.R., Larroche, C. 2008. Current Developments in Solid-state Fermentation. Springer, New York, USA. 517 p.

Pelizer, L.H., Pontieri, M.H., Moraes, I. de O. 2007. Utilização de resíduos agro-industriais em processos biotecnológicos como perspectiva de redução do impacto ambiental. Journal Technology Management \& Innovation 2: 118127.

Rahardjo, Y.S.P., Tramper, J., Rinzema, A. 2006. Modeling conversion and transport phenomena in solid-state fermentation: a review and perspectives. Biotechnology Advances 24: 161-179.

Rodriguez-Zúñiga, U., Farinas, C., BertucciNeto, V., Couri, S., Crestana, S. 2011. Aspergillus niger production of cellulases by solid-state fermentation. Pesquisa Agropecuária Brasileira 46: 912-919.

Saha, K., Maity, S., Roy, S., Pahan, K., Pathak, R., Majumdar S. 2014. Optimization of amylase production from B. amyloliquefaciens (MTCC 1270) using solid state fermentation. International Journal of Microbiology 2014: 1-7.

Sena, A.R., Koblitz, M.G.B., Goes Neto, A., Uetanabaro, A.P.T. 2006. Seleção de fungos do semi-árido baiano secretores de hidrolases de interesse em alimentos. Sitientibus 35: 91-98.

Shafique, S., Bajwa, R., Shafique, S. 2009. Screening of Aspergillus niger and A. flavus strains for extra cellular alpha-amylase activity. Pakistan Journal of Botany 41 (2): 897-905.

Silva, M.F., Fornari, R.C.G., Mazutti, M.A., Oliveira, D., Padilha, F. F., Cichoski, A.J., Cansian, R.L., Luccio, M.D., Treichel, H. 2009. Production and characterization of xanthem gum by Xanthomonas campestres using cheese whey as sole carbon source. Jornal of Food Engineering 90: 119-12.

Singhania, R.R., Sukumaran, R.K., Patel, A.K., Larroche, C., Pandey, A. 2010. Advancement and comparative profiles in the production technologies using solid-state and submerged fermentation for microbial cellulases. Enzyme and Microbial Technology 46: 541-549.

Siqueira, F.G. 2010. Perfil das Holocelulases de Penicillium corylophylum (INPA) crescido em diversos fontes de carbono lignocelulolítico. $277 \mathrm{f}$. (PhD Thesis) - University of Brasília, Brasília, Brazil.

Soffner, M.L.A. P. 2001. Produção de polpa celulósica a partir de engaço de bananeira. $70 f$. (M.Sc. Thesis), University of São Paulo, São Paulo, Brazil.

Souza, O., Federizzi, M., Coelho, B., Wagner, T.M., 
Santos et al. (2018) / Enzyme production by soil filamentous...

Wisbeck, E. 2010. Biodegradação de resíduos lignocelulósicos gerados na bananicultura e sua valorização para a produção de biogás. Revista Brasileira de Engenharia Agrícola e Ambiental 14: 438-443.

Whitaker, J.R. 1994. Effect of substrate concentration on rates of enzyme-catalyzed reactions. In: WHITAKER, J.R. (eds.) Principles of enzymology for the food Sciences. Marcel Dekker, New York, USA. p. 182-186. 